\title{
PEMBUATAN RUMAH SINGGAH SEBAGAI BENTUK PENINGKATAN MINAT BELAJAR GENERASI Z DI KELURAHAN MUARA FAJAR BARAT
}

\author{
${ }^{1)}$ Fitra Ramdhani, ${ }^{2)}$ Rizki Ramadhan Husaini, ${ }^{3)}$ Sukri \\ ${ }^{1,2)}$ Program Studi Teknik Sipil Fakultas Teknik Universitas Abdurrab \\ ${ }^{3}$ Program Studi Teknik Informatika Fakultas Teknik Universitas Abdurrab \\ 1,2,3) Jl. Riau Ujung No 73 Pekanbaru - Riau - Indonesia \\ email: fitra.ramdhani@univrab.ac.id, rizki.ramadhan@univrab.ac.id, sukri@univrab.ac.id
}

\begin{abstract}
ABSTRAK
Kondisi di kelurahan Muara Fajar Barat khususnya RW 03 masih terdapat beberapa permasalahan terutama pada anak-anak generasi $Z$. Generasi $Z$ ini adalah anak yang lahir di zaman yang serba dengan teknologi. Hal ini yang menyebabkan anak-anak pada generasi $Z$ menggunakan digital yaitu gadget tanpa diringi dengan pengetahuaan penggunaan gadget yang tepat dan filtrasi penggunaan gadget dan pengawasan dari orang tua. Sehingga anak-anak kecanduan dengan gadget bukan untuk hal yang positif tetapi lebih ke hal yang negative. Kecanduan gadget inilah yang mempengaruhi akademik dan pendidikan serta sosial emosi anak-anak pada generasi Z. Hal ini dapat dilihat dengan kurangnya minat belajar anak, ketidakberhasilannya anak-anak di sekolah, dan banyak anak-anak yang putus sekolah. Menindak lanjuti hal ini, maka tim pengabdian mempunyai usulan dengan membuat program Rumah Singgah. Program rumah singgah ini bertujuan sebagai wadah bagi anak-anak pada generasi $Z$ ini untuk meningkatkan minat belajar dan mengerjakan tugas serta diskusi dengan teman-temannya serta dapat mengembangkan bakat kreativitas dan inovasi. Hasil dari pengabdian ini terwujudnya rumah singgah yang sangat bermanfaat bagi masyarakat khususnnya anak-anak pada generasi $\mathrm{Z}$ di Kelurahan tersebut. Hal ini dapat dilihat dengan ramainya pengunjung rumah singgah dari golongan anak-anak yang menggunakan rumah singgah sebagai tempat singgah, berkumpul, belajar kelompok dan membaca.
\end{abstract}

Kata kunci: Generasi Z, Rumah Singgah, Minat Belajar

\section{ABSTRACT}

Conditions in Muara Fajar Barat sub-district, especially $R W$ 03, still have a number of problems, especially in children of Generation Z. This Generation $Z$ is a child born in an age that is all in technology. This is what causes children in generation $Z$ to use digital gadgets that are not accompanied by knowing the proper use of gadgets and filtration of gadget use and supervision from parents. So that children addicted to gadgets are not for positive things but rather negative things. This gadget addiction has influenced the academic and educational and social emotions of children in Generation Z. This can be seen by the lack of interest in children's learning, the failure of children in school, and many children who drop out of school. Following this up, the dedication team had a proposal by creating a Shelter House program. This shelter program aims as a place for children in generation $Z$ to increase interest in learning and doing assignments and discussions with friends and can develop talents of creativity and innovation. The result of this service is the realization of a shelter that is very useful for the community, especially children in Generation $Z$ in Muara Fajar Barat sub-district. This can be seen by the crowds of shelters from the group of children who use the shelter as a haven, gather, study groups and read.

Key words: Generation Z, Shelter house, Interest in Learning

\section{PENDAHULUAN}

Kelurahan Muara Fajar Kecamatan Rumbai melakukan pemekaran pada Tahun 2018 dan terbentuklah dua kelurahan yaitu Kelurahan Muara Fajar Barat dan Kelurahan Muara Fajar Timur, keduanya berada bersebrangan hanya dibatasi oleh jalan Lintas Sumatra. Fasilitas fasiltas umum pun banyak berada di Kelurahan Muara Fajar Timur seperti Masjid, Sekolah dan Tempat Pembuangan Akhir Sampah. Dan sampai saat ini 
masyarakat Kelurahan Muara Fajar Barat dan Kelurahan Muara Fajar Timur masih menggunakan fasilitas yang sama.

Kelurahan Muara Fajar Barat memiliki keadaan Geografs dengan curah hujan 190-192 $\mathrm{cm}^{3}$, Kecepatan Angin 14-15 Km/jam, Kelembaban udara 96\%, Suhu 28-30 ${ }^{\circ} \mathrm{C}$ dengan luas wilayah 9,4 Km2. Kelurahan Muara Fajar Barat terdiri dari 26 Rukun Tetangga (RT), 7 Rukun Warga (RW) dengan jumlah kepala keluarga 1324 jiwa dan jumlah keseluruhan penduduk mencapai 5312 jiwa serta mayoritas penduduk Kelurahan Muara Fajar Barat beragama Islam. Kondisi di kelurahan Muara Fajar Barat khususnya RW 03 masih terdapat beberapa kekurangan. Dari jumlah penduduk yang ada sebagian penduduk terdiri dari anak-anak yang berada pada generasi Z. Dimana anak-anak pada generasi $\mathrm{Z}$ ini anak yang lahir di zaman yang serba dengan teknologi khususnya teknologi digital. Hal ini yang menyebabkan anak-anak pada generasi $\mathrm{Z}$ menggunakan digital yaitu gadget tanpa diringi dengan pengetahuaan penggunaan gadget yang tepat dan filtrasi penggunaan gadget dan pengawasan dari orang tua. Sehingga anak-anak kecanduan dengan gadget bukan untuk hal yang positif tetapi lebih ke hal yang negative, seperti penggunaan gadget untuk permainan game, social media, you tube dan lain sebagainya. Kecanduan gadget inilah yang mempengaruhi akademik dan pendidikan serta sosial emosi anak-anak pada generasi Z. Hal ini dapat dilihat dengan kurang nya minat belajar anak, ketidakberhasilannya anak-anak di sekolah, dan banyak anak-anak yang putus sekolah.

Menindak lanjuti hal ini, maka tim pengabdian mempunyai usulan dengan membuat program Rumah Singgah. Program rumah singgah ini bertujuan sebagai wadah bagi anak-anak pada generasi $\mathrm{Z}$ ini untuk meningkatkan minat belajar dan mengerjakan tugas serta diskusi dengan teman-teman nya serta dapat mengembangkan bakat kreativitas dan inovasi. Dengan adanya rumah singgah ini semoga bisa menjadi tempat yang tepat bagi anak-anak pada generasi $\mathrm{Z}$ yang tadinya anak-anak pulang sekolah lupa akan belajar dan tugasnya serta sibuk dengan aktivitasnya sendiri dengan gadget nya. Dengan adanya rumah singgah ini mereka mempunyai aktivitas dan memanfaatkan waktu untuk hal- hal yang positif.

\section{TINJAUAN PUSTAKA}

\section{Rumah Singgah}

Pengertian rumah singgah secara harfiah merupakan suatu tempat persinggahan, mampir, ataupun tempat berhenti dan beristirahat sebentar saat dalam perjalanan tetapi meliputi berbagai tempat kegiatan yang dimanfaatkan sebagai model sarana belajar dan bermain bagi anak-anak [1]. Dalam pelaksanaan kegiatan Program ini, proses pembentukan Rumah Singgah dilakukan dengan tujuan menjadi wadah atau tempat anak-anak bermain dan belajar. Dengan fungsi rumah singgah sebagai fasilitator, (sebagai penyambung anak-anak kepada keluarga, lembaga), kuratif dan rehabilitatif merupakan tempat mengembalikan dan menanamkan fungsi sosial bagi anak, hubungan Informal sehingga dapat menciptakan hubungan kekeluargaan antar anak-anak, 
persinggahan dari jalan, sekolah, rumah temen kerumah. Selain itu fungsi rumah singgah yaitu sebagai sumber belajar masyarakat melalui program pendidikan non formal, tempat rekreasi melalui bahan bacaan, memperkaya pengalaman belajar, menumbuhkan kegiatan belajar dan latihan tanggung jawab melalui ketaatan terhadap aturan yang diterapkan [2].

\section{Generasi $Z$}

Generasi $Z$ adalah orang-orang yang lahir pada tahun 1995 sampai dengan tahun 2010. Generasi $Z$ ini mempunyai intensitas yang tinggi dalam penggunaan teknologi informasi dan komunikasi. Anak pada generazi $Z$ ini harus diberi bekal dalam keterampilan berpikir kritis, berpikir inovatif, pemecahan masalah dan interaksi sosial. Oleh karena itu, sekolah memiliki tanggungjawab dalam hal ini melalui kegiatan pembelajaran. Upaya lain yang dilakukan yaitu dengan kolaborasi bersama orang tua, sekolah, guru mata pelajaran, wali kelas, dan instansi/lembaga/perusahaan yang bergerak di bidang teknologi informasi dan komunikasi [3].

Generasi Z mempunyai kemampuan untuk mengaplikasikan semua kegiatan dalam satu waktu (multi tasking) antara lain menjalankan sosial media menggunakan ponsel, browsing menggunakan pc, dan mendengarkan musik menggunakan headset. Apapun yang dilakukan kebanyakan berhubungan dengan dunia maya. Hal ini dikarenakan generasi ini sudah mengenal teknologi dan akrab dengan gadget canggih yang secara tidak langsung berpengaruh terhadap kepribadian sejak mereka lahir. Forbes Magazine membuat survey terhadap 49 ribu anak-anak tentang generasi $\mathrm{Z}$ di Amerika Utara dan Amerika Selatan, di Afrika, di Eropa, di Asia dan di Timur Tengah. [4]. Berdasarkan hasil penelitiannya menyatakan bahwa generasi $\mathrm{Z}$ merupakan generasi global pertama yang nyata, karena generasi $\mathrm{Z}$ ini nantinya merupakan karyawan yang efektif di era digital bagi perusahaan sehingga pengusaha harus mengikuti perkermbangan era digital untuk perusahaannya[5]. Selain itu, dengan bangkitnya generasi $\mathrm{Z}$ juga akan menimbulkan tantangan baru bagi praktek manajemen dalam organisasi, khususnya bagi praktek manajemen sumber daya manusia [6].

Penentuan Gaya Belajar Usia Remaja Dengan Membandingkan Efektifitas Antara Metode Certainty Faktor Dan Demster-Shafer terkait tentang bagaimana mengukur gaya belajar audio, visual dan kinestetik) yang dibantu dengan menggunakan metode certainty factor dan demster-shafer. Sehingga memudahkan remaja menemukan gaya belajar yang dimilikinya [7]. Sedangkan penelitian lainnya mengenai Hubungan Iklim Kelas Dengan Motivasi Belajar Siswa Smk Abdurrab menjelaskan bahwa iklim kelas mempengaruhi motivasi belajar pada siswa,. Iklim belajar yang tepat dan disesuaikan dengan gaya belajar serta budaya yang berkembang, akan memengaruhi motivasi siswa dalam belajar [8]. Salah satu strategi solusi yang ditawarkan peneliti adalah memberikan penyuluhan tentang literasi digital pada remaja agar cerdas dan bijak menggunakan sosial media, serta memberikan pelatihan memanfaatkan media sosial untuk berbisnis [9]. Semakin banyaknya pusat perbelanjaan, tempat karaoke, dan taman rekreasi yang 
semakin banyak didirikan, membuat mereka lebih banyak meluangkan waktu ke tempat hiburan daripada membaca buku di perpustakaan maupun taman baca[10]

\section{METODE PELAKSANAAN}

Metode Pelaksanaan Kegiatan program rumah singgah terdiri dari beberapa tahap yaitu:,

1. Tahap pertama: melakukan survei lokasi dan tempat untuk rumah singgah di RW 03, RT 02 Kelurahan Muara Fajar Barat,

2. Tahap kedua: mendesain dan memberikan inovasi yang tepat untuk rumah singgah

3. Tahap ketiga: melakukan persiapan media pembelajaran untuk rumah singgah

4. Tahap keempat: peresmian sekaligus mengaktivkan rumah singgah

5. Tahap kelima: melakukan evaluasi terhadap dampak rumah singgah kepada anakanak yang menggunakan rumah singgah.

Metode pendekatan yang ditawarkan untuk menyelesaikan permasalahan mitra dalam kegiatan pengabdian kepada masyarakat ini adalah

\section{Wawancara}

Dalam pengabdian ini akan dilakukan wawancara kepada pihak Mitra baik itu kepada Ketua Rw 03, RT 02, para orang tua, anak-anak generasi Z di RW 03. Wawancara ini dilakukan dengan teknik wawancara tidak terstruktur atau terbuka. Wawancara tidak terstruktur merupakan wawancara dimana pertanyaan tidak disusun terlebih dahulu, melainkan disesuaikan dengan keadaan dan ciri yang unik dari Mitra, sehingga tanya jawab mengalir seperti dalam percakapan sehari-hari. Tujuan dari wawancara tidak terstruktur ini adalah untuk memperoleh keterangan yang terinci dan mendalam. Pembahasan yang di tanyakan saat wawancara adalah terkait dengan keluhan masyarakat terhadap pemanfaatan digital atau smart phone di masyarakat terutama pada anak-anak.
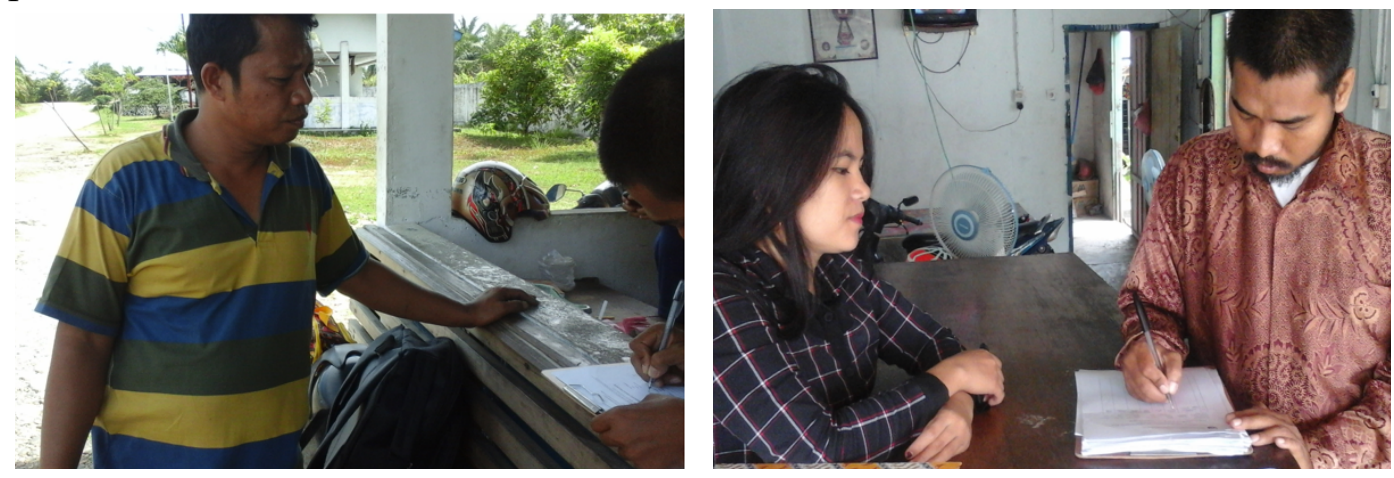

Gambar 1. Dokumentasi Wawancara

\section{Observasi}


Pada tahap observasi ini dilakukan untuk mengamati dan melihat secara langsung kebiasaan anak-anak remaja pada saat berkumpul, kegiatan sehari-hari saat mereka berinteraksi, atau nongkrong. Pengamatan ini dilakukan supaya mendapatkan data yang lebih objektif dan sesuai dengan kenyataan dilapangan. Media yang dilakukan untuk melakukan observasi ini adalah sebagai berikut:

1. Buku dan Pulpen, sebagai alat untuk mencatat hasil pengamatan

2. Kamera, digunakan untuk mengambil gambar sebagi dokumentasi dari hasil pengamatan

\section{Evaluasi}

Evaluasi ini merupakan tahapan terakhir dari seluruh rangkaian kegiatan dalam Program Kemitraan Masyarakat di Rumah Singgah. Evaluasi yang dilakuan pada tahap akhir ini adalah dengan cara melihat seberapa banyak anak-anak pada generasi $\mathrm{Z}$ menggunakan Rumah Singgah.

\section{Partisipasi Mitra}

Dalam pelaksanaan Pegabdian Masyarakat ini di Rumah Singgah, Partisipasi Mitra dapat dilihat pada saat melakukan wawancara dan observasi, dimana Mitra berpartisipasi dalam pemberian data secara lengkap yang dibutuhkan dalam pengabdian ini. Selain itu partisipasi mitra pada saat melakukan penyusunan dalam perencanaan program, dimana Mitra berpatisipasi melakukan sumbangsih ide dalam penyusunan program

\section{HASIL DAN PEMBAHASAN}

Program Rumah singgah berlokasi di Jalan Yos Sudarso No. 95 Kelurahan Muara Fajar Barat di RT 02 RW 03. Rumah Singgah ini merupakan rumah dari salah seorang warga di RT 02 dan RW 03 yang dizinkan untuk dibuatkan rumah singgah.

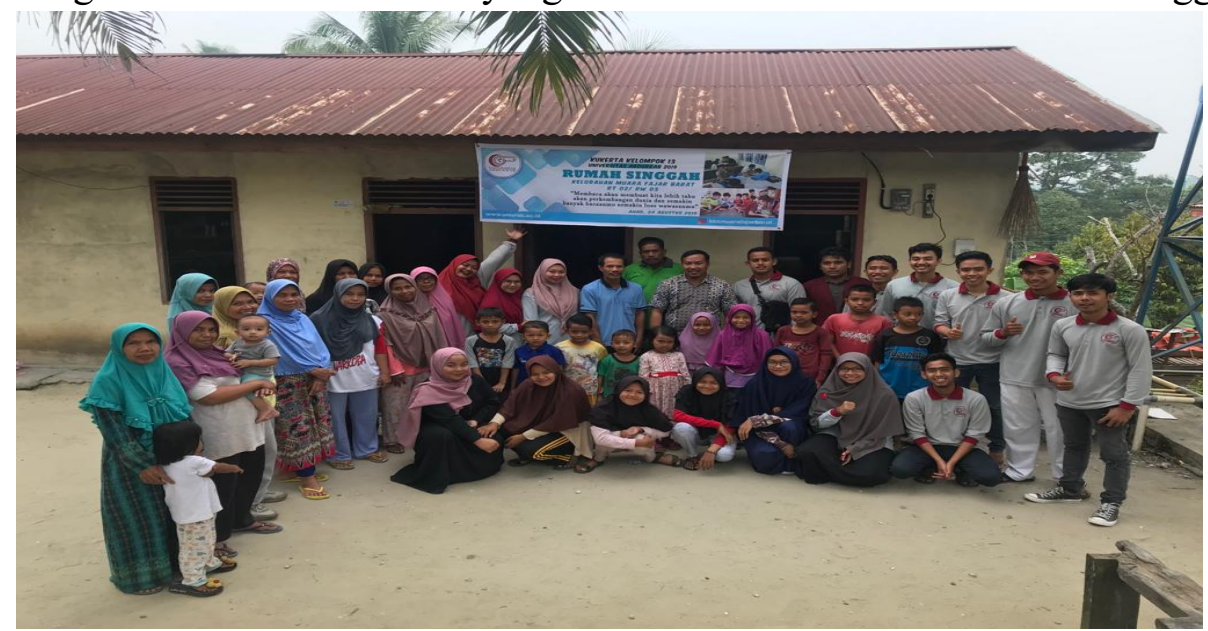

Gambar 2. Peresmian Rumah Singgah Universitas Abdurrab di Kelurahan Muara Fajar Barat

Peresmian rumah singgah Universitas Abdurrab dapat dilihat pada Gambar 1. di atas. Peresmian rumah singgah ini dihadiri oleh perangkat desa yaitu Ketua RT. 
02, RW 03, Ibu-ibu PKK, Pemuda Masyarakat, masyarakat dan anak-anak pada generasi Z. Peresmian ini disambut baik dan antusias oleh masyarakat.

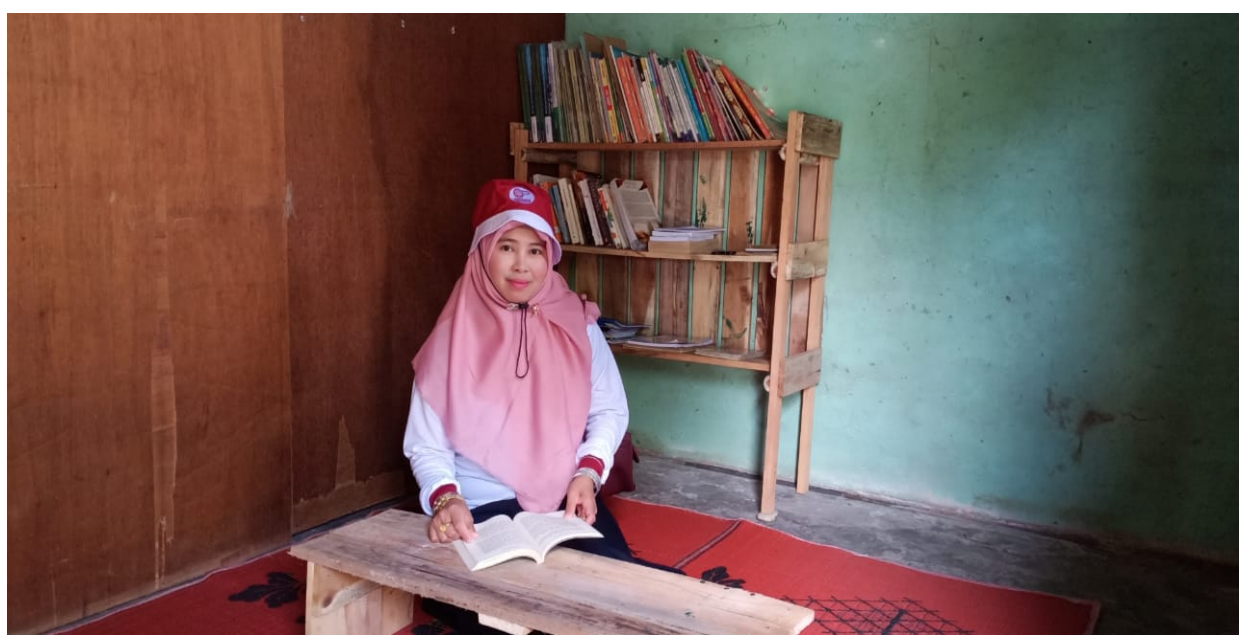

Gambar 3. Kondisi Rumah Singgah

Kondisi Rumah Singgah ini masih belum sempurna seperti yang diharapkan. Pada tahap awal ini fasilitas yang ada yaitu buku belajar dan meja belajar. Tim pengabdian bersama perangkat desa berusaha untuk memenuhi fasilitas kebutuhan rumah singgah ini sebaik mungkin. Sehingga rumah ini dapat dimanfaatkan sebaik-baiknya dan anak-anak betah dan senang untuk berada di rumah singgah.

Berdasarkan pengamatan selama beroperasinya rumah singgah ini di Kelurahan Muara Fajar Barat bahwa ramainya pengunjung yang menggunakan rumah singgah ini untuk tempat membaca dan belajar serta membuat tugas dari sekolah. Pengunjung tidak hanya berasal dari RT 02 saja.

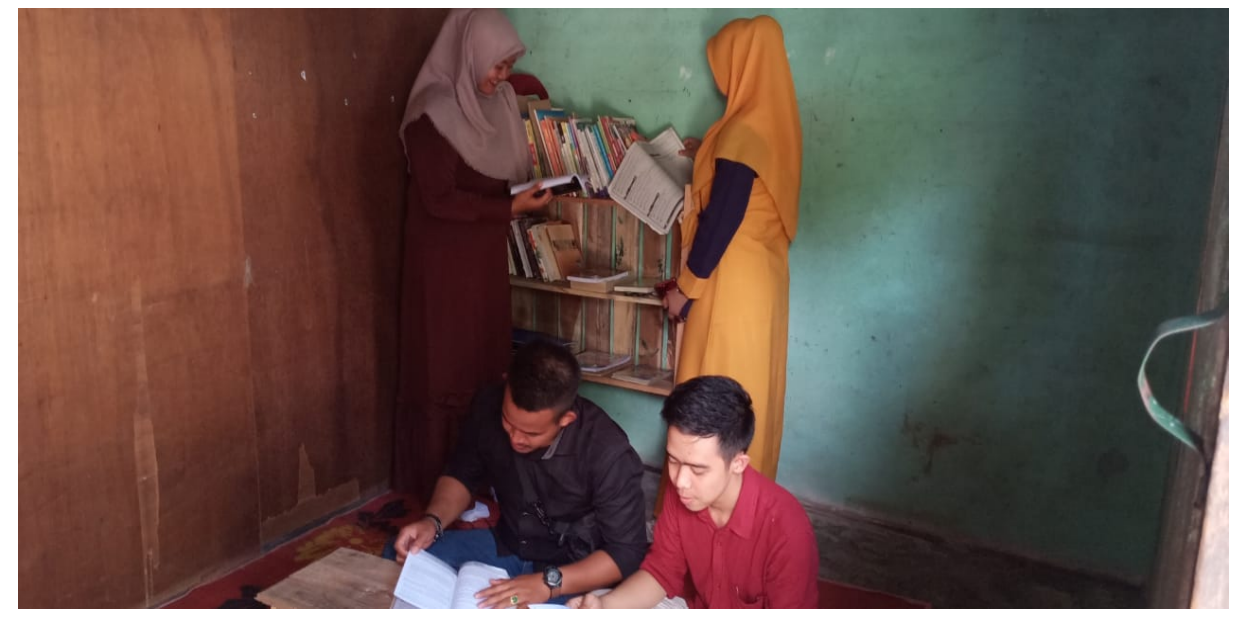

Gambar 4. Pengunjung Rumah Singgah

\section{KESIMPULAN}


Berdasarkan hasil pengabdian yang dilakukan oleh tim pengabdian dosen Universitas Abdurrab yang diadakan di Kelurahan Muara Fajar Barat pada bulan Agustus tahun 2019 sangat bermanfaat bagi masyarakat di Kelurahan Muara Fajar Barat khususnnya anak-anak pada generasi $\mathrm{Z}$ di Kelurahan tersebut. Hal ini dapat dilihat dengan ramainya pengunjung rumah singgah dari golongan anak-anak yang menggunakan rumah singgah sebagai tempat singgah, berkumpul, belajar kelompok dan membaca.

\section{Saran}

Dari pengabdian yang dilakukan oleh tim diharapkan dapat menjangkau lebih banyak pengunjung yang datang ke rumah singgah dengan membuat rumah singgah lebih baik dari kondisi yang ada pada saat ini. Diharapkan juga kepada masyarakat yang bisa memberikan donasi buku atau donasi dalam bentuk material dalam upaya meningkatkan kualitas dan fasilitas rumah singgah yang ada.

\section{DAFTAR PUSTAKA}

[1] Aribowo, Ibnu. 2009. Upaya Pemberdayaan Anak Jalanan Melalui Rumah Singgah Diponegoro Yogyakarta. Vol, 3. No. 1

[2] S. S. Retno, Y. Rohmiyati, and J. Husna, "Pemberdayaan masyarakat melalui perpustakaan: studi kasus di rumah pintar 'Sasana Ngudi Kawruh' Kelurahan Bandarharjo-Semarang," J. Ilmu Perpust., vol. 4, no. 2, pp. 157-166, 2015.

[3] Bakti. C. P. and Safitri, N. E. 2017. Peran Bimbingan dan Konseling Untuk Menghadapi Generasi Z Dalam Perspektif Bimbingan dan Konseling Perkembangan. J. Konseling GUSJIGANG, vol. 3, no. 1.

[4] Dill, K. 2015. 7 Things Employers Should Know About The Gen Z Workforce, Forbes Magazin, 11.6..

[5] Elmore, T. 2014.. How Generation Z Differs from Generation Y. Retrieved July 01, Nasution, I. N., \& Syaf, A. 2018. Hubungan Iklim Kelas Terhadap Motivasi Belajar Siswa Smk Abdurrab. Psychopolytan (Jurnal Psikologi), 1(2), 98-110.

[6] Putra. Y. S. 2017. Theoritical review: Teori perbedaan generasi, J. Ilm. Among Makarti, vol. 9, no. 18.

[7] Syaf, Auliya. 2018. Comparison of the Effectiveness of Certainty Factor vs Dempster-Shafer in the Determination of the Adolescent Learning Styles. Proceeding Electrical Engineering and Informatics (ICon EEI), International Conference on Electrical Engineering and Informatics

[8] Syaf, Auliya. 2018. Hubungan Iklim Kelas terhadap Motivasi Belajar Siswa SMK Abdurrab. Psychopolytan: Jurnal Psikologi.

[9] P. D. Yulianti and A. Handayani, "Pkm Literasi Digital Pada Remaja Karang Taruna Di Kelurahan Tandang Kecamatan Tembalang Kota Semarang: Cerdas Dan Bijak Menggunakan Media Sosial Di Era Digital," 2018.

[10]Z. Arifin, "Peran Taman Bacaan Masyarakat (Tbm) Mata Aksara Dalam Menumbuhkan Minat Baca Masyarakat Tegalmanding, Sleman, Yogyakarta," J. Elektron. Mhs. Pend. Luar Sekolah-S1, vol. 5, no. 1, 2016. 